\title{
From French Indochina to Paris and back again: The Circulation of Objects, People, and Information, 1900-1932
}

\author{
*Nélia Dias
}

\begin{abstract}
This article examines the ways in which the processes of collecting, ordering and governing were imbricated both in the metropole and in the colony. Focused on the ethnographic missions carried out by the Musée d'Ethnographie du Trocadéro (MET) and by the École Française d'Extrême Orient from 1900 to the 1930s, the paper explores the network of local collectors, the methodological protocols and standards, the collecting practices, and how objects were gathered in the field for displays at the MET in Paris and at the forthcoming ethnological museum at Dalat in French Indochina (what is now Vietnam). The article argues that the circulation of objects, and the information related to those objects, conceives both the metropole and the colony as sites for the production of ethnological knowledge. It also seeks to demonstrate that collecting practices entailed distinct government effects both in metropolitan France and in colonial Indochina.
\end{abstract}

Key words: Museum, ethnology, anthropology, Mauss, Rivet, colonial Indochina, collecting practices, circulation of objects and information.

The article deals with fieldwork/museum relations by focusing on the circulation of people, information, and objects in former French Indochina by the Musée d'Ethnographie du Trocadéro (MET) in Paris, from 1937 onwards known as the Musée de l'Homme (MH). The specificity of French ethnology 1 resides in the close links between the development of fieldwork and the museum, while in other national contexts, namely the Anglophone traditions, fieldwork is related to the emergence of the university as anthropology's primary institutional setting. Moreover, whereas the literature on the fieldwork missions has mostly focused on France's West African colonies, this article focuses on the MET's missions in former French Indochina in order to examine the ways in which the processes of collecting, ordering and governing were imbricated both in the metropole and in the colony. In doing so, it also points out how ethnological knowledge was produced in both locations by means of the circulation of objects and the information related to them.

The argument is developed in three parts; the first section of the article examines two methodological instructions, elaborated in the early twentieth-century by Marcel Mauss and by the École Française d'Extrême-Orient (EFEO) respectively, that emphasize the role of material objects in particular, and of ethnography in general, within colonial governance; namely in what concerns the development of 'humane colonial practices'. Here I analyze why these two methodological procedures did not produce concrete results in terms of collecting practices due, in large part, to the absence of coordination with metropolitan museological and research institutions. The second part of the article explores Paul Rivet's mission in French Indochina, and the setting up of a network of local collectors and their relationships with the metropolitan museum. By analyzing the collecting practices, and the circulation of objects and information from the field to the metropole and back again during a short period, from 1931 to 1934 , I aim to analyze the role played by local collectors on the one hand, and on the other to explore the ways in which objects were gathered in the field for displays at the MET and at the forthcoming ethnological museum at Dalat. If the MET played the role of a coordinating research centre located in the metropolis, the EFEO played a similar role in the colony, where it provided methodological expertise, conducted inquiries and constituted collections that were duplicates 
of those of the MET. By examining the practices involved in the processes of assembling and displaying the Indochinese collections at the MET, this article seeks to highlight the diverse forms of agency embodied in these processes.

The circulation of objects and information from the field to the metropolitan museum as back again was made possible due to common methodological protocols and standards. The third part of the article therefore analyzes the methodological procedures underlying the practices of collecting, showing how ethnographic data was produced thanks to the conventions for describing and classifying objects, and the practices of inscription associated with them. The focus on fieldwork and museums helps to illuminate the connections between practices and places (Strasser 2012: 310) as well as the affinities between ethnology and other sciences grounded in collecting practices. The methodological procedures made it possible for information and objects to circulate between colony and metropole, inscribing collections in new networks through which a range of governing effects were produced. This article thereby aims to foster broader reflection on the ways in which collecting embodied distinct epistemic values and governing effects according to metropolitan and colonial contexts.

\section{Mauss: Facts, Objects, and 'Humane Colonial Practices'}

Indochina occupied a distinctive place among other French colonies, due in large part to the role played by the EFEO. Created in 1899, and based first in Saigon and later in Hanoi, the EFEO was the main research centre focused on the archaeology and linguistics of ancient Asian civilizations (Clémentin-Ojha and Manguin 2001; Singaravélou 2009). Therefore, thanks to its first director, Louis Finot, who was Marcel Mauss's professor of Sanskrit at the École Pratique des Hautes Études (EPEH), the EFEO also aimed to extend its competencies to include ethnology, a concern that echoed the demands for knowledge and information on indigenous societies which came from colonial administrations. Thus, the EFEO conducted a series of initiatives devoted to gathering data on indigenous languages and traditions in order to fill the gap in French scientific interest in their own colonies. This presumed lack of scientific interest can be considered a sort of trope, continuously repeated and reiterated by French scholars, including Mauss himself in 1913. Indeed, Durkheimians were, as Alice Conklin notes, 'particularly critical of the descriptions published by military officers, colonial administrators or judges in France's sub-Saharan and Asian territories, accusing them of being too preoccupied with their "real jobs" to produce professional descriptions of social facts' (2013: 80 footnote 48).

Assembling information and objects on Indochinese societies served undoubtedly colonial interests, mainly in what concerns the management of colonial populations, a principle acknowledged by the Sanskritist Émile Senart in a letter addressed to Finot. ${ }^{2}$ As founder of the Comité de l'Asie française, a colonial lobby group advocating French rule in Indochina, Senart was strongly partisan towards a scientific colonisationcolonisation savante; moreover, as a member of the Académie des Inscriptions et Belles-Lettres, he represented this institution at the 1902 First International Congress for Oriental Studies at Hanoi. Mauss was invited to give a presentation at this Congress, which was organised by one of his former students, Claude-Eugène Maître. As he was unable to attend this event, Mauss's presentation, entitled 'Essay for an instruction to the sociological study of Indochinese societies', was read by his close collaborator, Henri Hubert (Singarévelou 2009: 76-7) and its abstract published in the Congress' report (Mauss 1903: 115-6). The manuscript, albeit incomplete, entitled 'The utility of descriptive sociological researches in French Indochina' is preserved amongst Mauss's papers (Fournier 1994: 355-7; Bert 2011).

The very beginning of Mauss's manuscript starts with what he designated an 'accepted axiom': to administer it is necessary to know the people who are administered (Mauss in Bert 2011: 149). This implicit reference to Senart's letter, published a year earlier, is not surprising, since he was supposed to attend the Congress. In addition to referring to the 'accepted axiom', Mauss emphasised the ways in which 'colonial policy may be the area in which the old adage "knowledge is power" (savoir c'est pouvoir) is best confirmed' (Mauss in Bert 2011: 149). Mauss's references to the 'accepted axiom' and to the 'old adage' might be considered both as a means of distancing himself from explicit colonial stances, and at the same time a way of implicitly positioning himself in line with colonial concerns. In other words, for Mauss, the 
relationships between ethnographic knowledge and colonial administration were unavoidable.

The rich insights highlighted by Mauss in his instruction deserve a detailed analysis that goes beyond the scope of this article, but I will focus here only on three aspects. First, as Émile Durkheim's faithful disciple, Mauss coined the term 'descriptive sociology', as equivalent to ethnography, to designate 'the accurate register/record of all aspects regarding a specific social group' (Mauss in Bert 2011: 153). It was descriptive sociology's task to collect facts on beliefs, habits, customs, traditions, and languages, envisaged as ways of acting, feeling, and thinking. Since Mauss's instruction was addressed to a larger audience (colonial officers, missionaries from different denominations, doctors, colonial civil servants and indigenous savants'), it was deemed to be merely indicative, by providing untrained observers with 'some rules', or, as he put it, 'some methodological principles' (Mauss in Bert 2011: 151-2). One of the distinctive methodological principles was to observe and collect social facts, as realities external to the individuals, which are expressed by ways of acting, feeling, and thinking in Western as well as non-Western societies.

Second, the focus put on material objects, their study, acquisition, and classification, is worth noting. For Mauss 'every way of acting or of collective thinking is expressed by or translated into a material instrument' (Mauss in Bert 2011: 155). By somehow reversing Durkheim's dictum, Mauss envisaged material things not as mere illustrations of social facts but as social facts themselves. The focus on the acquisition and classification of objects was probably related to the EFEO's concern for establishing museums all over French Indochina. Indeed, a general museum dedicated to Indochina was created, thanks to Finot, at Saigon, which moved to Hanoi, where the EFEO's headquarters were located, in 1902 (Singaravélou 2009: 79).

Third and last: in addition to expressing the concreteness of social facts, objects were also material proof, and as such were useful evidence in proving the validity of assertions (Mauss in Bert 2011: 156). Along with photographs, phonograph recordings and, eventually, cinema, objects were deemed to play the role of pièces à conviction: in short they were somehow the equivalent of material testimonies in the absence of written records.

The ethnographic research on Indochinese societies presented for Mauss a scientific as well as a practical interest; since indigenous societies were on the edge of disappearance, it followed that there was urgency to systematically collect their material records (Mauss 1903: 115). As for what he called the 'practical interest', it resided in the ways in which the 'repertory of facts' would be essential for colonial administrations in improving the management of indigenous populations. Acknowledging the 'disasters' committed by previous French administrations due to the lack of information on colonised peoples, Mauss advocated respect for indigenous beliefs and customs as a way of implementing, as he put it, 'humane colonial practices' (Mauss in Bert 2011: 149). Thus, it followed that there was a need to compile and study facts on beliefs, habits, and customs as a means of acting on society. Moreover, by stating that 'one can only act on society from the interior', Mauss acknowledged that this apparently indirect form of action was in fact 'the unique form of direct action and an efficient one' (Mauss in Bert 2011: 150). In line with Durkheim's precepts, acting on society required a precise knowledge of its institutions. In other words, Mauss somehow appropriated the 'old adage' by emphasizing the ways in which scientific knowledge could be an adjunct of 'humane colonial practices'. This was a postulate reiterated by Finot in 1908 in his advocacy of 'an imperial policy', built upon the observation and compilation of facts on indigenous customs, beliefs, and languages. ${ }^{3}$ Thus, the academic research carried on by the EFEO would complement 'imperial policy' based on the 'coexistence of diverse races, each race keeping its own language, customs and beliefs' (Singaravélou 2009: 85).

In 1900 the EFEO issued an Instruction pour les collaborateurs de l'École Française d'Extrême-Orient, addressed to civil servants, missionaries, colonial administrators, and travellers for collecting information on Indochinese history, races, languages and religions. ${ }^{4}$ As a portable and practical guide, this Instruction contained blank sheets at the end reserved for collaborators' annotations and remarks. The information assembled by collaborators would pave the way for further research, theoretical and analytical, to be carried on by EFEO's scholars. Although divided into three sections - archaeology, linguistics, and ethnography - the Instruction was therefore mainly devoted to linguistics (with more than sixty pages); whereas 
the sections dedicated to archaeology and to ethnography contained less than two pages. The section 'Ethnography', envisaged as a 'summary for an ethnographical study', contained thirteen sub-sections, ranging from habitation to hunting and fishing, means of transportation, agriculture, commerce, industry, war, society, art, and religion.

Although this Instruction didn't have a listed author, its affinities with the 1902 Mauss essay in particular, and with the Durkheimian methodological framework in general, are striking. Two features deserve mentioning. First, the focus was put on facts and on precise terminology. EFEO's collaborators were asked to 'describe facts in an accurate way', to privilege direct observation over second hand information and to register the informant's name (Instruction 1900: 72). Collaborators were requested to avoid using vague terms, such as 'superstitions' and 'superstitious practices', an injunction that was also emphasized in Mauss's text, where observers were asked to avoid using the term 'superstition' and to replace it with 'religion' (Mauss in Bert 2011: 153). Second, we see echoes of Mauss and Durkheim in the quest for the underlying reasons behind social practices and for indigenous explanations; although 'local explanation was generally false', it nevertheless 'provides precious indications' (Instructions 1900: 72). It is worth noting that in his 1902 inaugural lecture, Mauss maintained that "the "savage" is the last person to know exactly what he thinks and what he does. The best information is normally false if we take it for granted'. ${ }^{5}$

Mauss's interest in methodological questions was a constant trait in his career; in addition to the Indochinese instructions, he had developed two questionnaires for Korea, one on folklore and another on technology, and envisioned in 1906-1907 an ethnographic instruction for West Africa and the Congo (Fournier 1994: 195). In 1913 he asserted that ethnography, like other sciences based upon observation, required three kinds of methods and institutions: fieldwork, museums and archives, and finally teaching (1969: 421). By equating ethnography with other 'sciences de plein air' such as zoology, botany, geology, as well as physical geography, Mauss acknowledged both their specificity (based on observation) and their contrast with laboratory sciences not based on collecting practices. It was also in 1913 that Mauss elaborated the idea of a Bureau of Ethnology, whose main aim would be to coordinate and develop ethnographic studies both in France and in French colonies (Conklin 2002: 33; Sibeud 2004), an initiative that ultimately was not realized.

Although acknowledging the scientific value of the surveys carried out by the EFEO (1969: $412 ; 428$ ), Mauss nevertheless pointed out the fragmentary dimension of these enterprises due to the absence of a systematic and concerted directorship. In fact, ethnography was far from being the EFEO's main intellectual concern, due to its archaeological and philological framework. Yet the Orientalist tradition as expressed by the EPHE and the EFEO undoubtedly played a key role in Mauss's career. Among Mauss's former students, Maître was EFEO director from 1908 to $1920^{6}$ and Paul Mus, a specialist in Buddhism, was a collaborator with EFEO between 1927 and 1937. As Mauss acknowledged, his own election in 1930 at the Collège de France was greatly indebted to the EFEO in general and to Finot in particular. ${ }^{7}$ In addition, Finot was member of the directory of the Institut d'Ethnologie de Paris (IEP) (Fournier 1994: 506) and along with Paul Rivet convinced Pierre Pasquier, the Governor-General of Indochina, to begin planning an ethnographic museum in the 1920s (Conklin 2002: 38). Plans for an economic and ethnographic museum began in 1924, and a specific commission was created by decree in July 1929, but it was only in the wake of Rivet's mission to Indochina that all these initiatives actually took shape (Dias 2014).

There were efforts to train observers and gather information in French Indochina to be sent to the metropolitan centre which predated Rivet's mission in 1932, but it was mainly in the late 1920s and the early 1930s that a concerted and systematic connection between ethnology and practices of colonial governance gained consistency, thanks precisely to institutions such as the IEP (created in 1925) and the MET. As the MET's director since 1928, Rivet aimed to strengthen the links between museum, fieldwork and teaching/research. It was no accident that these two institutions patronised fieldwork in French colonies at the same time that the colonial administration's policies were underpinned by knowledge of governed subjects. Thus, the MET as a 'genuine colonial laboratory', as Rivet proclaimed in 1931 (Conklin 2013: 215), could fulfil the mediating role between the metropole and the colonies. In other words, the embryonic essays produced by Mauss were very much shaped by the institutionalization of 
ethnology in the academic sphere with the IEP training the future generation of fieldworkers and delivering a certificate in ethnology (Conklin 2013: 86-90; L'Estoile 2007: 110-111), and its close links with the MET.

\section{Rivet's Mission in Indochina: The Network of Collectors, Objects, and Information}

From 18 December 1931 to 1 April 1932, Paul Rivet travelled throughout French Indochina ${ }^{8}$ collecting objects both for the MET and for the planned ethnographic museum in Dalat. ${ }^{9}$ Since the MET was short of Asian material, one of Rivet's explicit aims was to fill the gaps in the museum collections. ${ }^{10}$ Rivet's mission in Indochina contrasts sharply with another MET mission, the Dakar-Djibouti one (from May 1931 to February 1933), which entailed assembling a team of researchers under the directorship of Marcel Griaule and conducting intensive ethnographic inquiries based on 'plural observation' (Jamin 1982: 91). Instead, Rivet spent two or three days in each place, mainly in order to collect objects and to set up a network of local collaborators, coordinated by Jean-Yves Claeys (in charge of the EFEO archaeological section) and under Rivet's own direction.

The correspondence between Rivet and Claeys provides useful information about which criteria were employed for selecting local collectors and how they were recruited, what kind of objects were collected and the methodological procedures governing the collecting practices, how the practices of labelling and filing inventory cards were standardized, and which pieces of textual and visual information were judged relevant to complement the artefacts. Thanks to this correspondence, it is possible to trace the process of establishing a research team and its outcomes once Rivet returned to Paris.

Rivet collected around 400 objects and paid collectors directly, or distributed money via Claeys, to acquire artefacts for the MET. The urge to fill in the gaps in the MET's Asian collection may explain the observation that 'two months after his arrival, Rivet wrote to Rivière (the MET's assistant director) that he [...] needed another 10,000 francs because he had bought so much - mostly prehistoric artefacts' (Conklin 2013: 216). In Napé (Laos) Rivet collected around forty objects, briefly described in a letter addressed to Claeys from 14 February 1932. In Guinhon (Vietnam) Rivet wrote to Claeys on 20 February 1932 that Le Quang-Trong, a Catholic with a degree in law, would be a 'useful collaborator' and a few weeks later, he was recruited to work with Claeys. On the 29 of February 1932, writing from Angkor, Rivet announced to Claeys that he had recruited the Indianist Suzanne Karpelès (an EFEO member and curator of the Royal Library at Phnom Penh) and mentioned the collecting practices carried on by Georgette Naudin, curator of the Musée Blanchard de la Brosse created in 1929 in Saigon. In his subsequent letters, Rivet referred to the envoys sent by Jean-Henri Peyssonnaux, curator of the Musée Khai Dinh (created under the scientific direction of the EFEO in 1923 at Hué) and adjunct-curator of the Musée Cham (later Musée Henri Parmentier) at Tourane. $\mathrm{He}$ also informed Claeys about the arrival of his two current students, Jeanne Cuisinier and Véra Sokoloff, to study and record indigenous songs and music in Malaysia. ${ }^{11}$ In addition to mobilizing curators and researchers, Rivet managed to convince travellers and the official representatives of the colonial powers (résidents), qualified as people 'of goodwill' (de bonne volonté), ${ }^{12}$ to collect objects for the MET.

Rivet's tireless efforts produced concrete results, thanks to the network of local collectors, in terms of increasing the Asian collections at the MET. Karpelès' collection contained some objects given by the Royal Library at Phnom Penh. ${ }^{13}$ Naudin collected 74 objects from the Kuy (Cambodia), and Peyssonnaux, in addition to sending iconographic documentation and a bibliography, ${ }^{14}$ conducted, upon Rivet's request, an ethnographic inquiry. Claeys dispatched 156 objects, photos, and films to the MET, and the EFEO in turn contributed 445 objects. But the most important collector was undoubtedly Madeleine Colani. With a doctoral degree in science and being a regular contributor to the EFEO's Bulletin, Collani had been collecting objects from Laos for the MET since October 1931 (that is, before Rivet's mission), in accordance with the 1931 Instructions. ${ }^{15}$ Along with her sister, Éléonore, she collected more than 2,300 objects, mostly archaeological, for the MET. To sum up, around 3,362 Asian objects entered the MET in the wake of Rivet's mission (Dupaigne 2001: 141-2). 
Most of the collections were almost immediately put on display at the MET; part of the collection gathered by Rivet was displayed from August to October 1932 in the exhibit Exposition de la mission Rivet en Indochine. ${ }^{16}$ Colani's regular exchange with the MET's personnel, particularly with Marcelle Bouteiller, the curator of the Asian collections, and her continuous shipments of objects, led to the exhibit Jouets Annamites (Toys from Annam), held at the MET from December 1932 to January 1933, as well as resulting in the opening of an Asian gallery with a huge Indochinese section in January 1934. In other words, collecting practices in the colony informed exhibition politics at metropolitan museums. Moreover, the fact that Indochinese exhibits at the MET took place between 1932 and 1934, at a time of political tension and widespread criticism of colonial policies in both the metropole and in French Indochina, is not irrelevant (Dias 2014). While 'pacification campaigns' were conducted in the colony, the MET's exhibits on Indochina were a form of symbolic capture and mastery of that space.

Rivet's task was primarily to establish a network of collectors whose work should be pursued, after his departure, by Claeys. In fact, in May 1932 Claeys carried on an intensive tour throughout French Indochina in order to strengthen the links with the local collaborators and to set up new relationships with résidents and colonial personnel. In a letter addressed to Rivet dated May 1932, Claeys reported the state of the team's work; he praised Karpelès's research (with whom he had been working on the inventory cards) and signalled Cong VanTrung's collaboration in compiling the inventories and the drawings of the objects collected by Karpelès. As a passionate advocate for ethnography, in Rivet's terms, Claeys attempted to pursue his master's vision through regular contact with collaborators, frequent visits, as well as checking the objects collected and supervising the shipments. In July 1933, Claeys made another tour throughout French Indochina, mainly to visit local collectors; he noted that the number of collaborators hadn't increased, stated that Naudin was still filing the inventory cards and Karpelès was expecting his visit to ship her collection of religious objects from Cambodia and Laos. ${ }^{17}$ In 1934, Claeys acquired the objects collected by György Dobo (later Georges Devereux), who, thanks to Rivet, had obtained a Rockefeller grant to do his doctoral dissertation on the Moï. ${ }^{18}$ Claeys's activities in terms of centralizing and dispatching the ethnographic collections, assembled by the network of collaborators, effectively meant that the EFEO became a coordinating centre.

The MET therefore played, to a certain extent, the role of a 'center of calculation', in Bruno Latour's terms (1987: 215-57): that is, a place where objects, photographs, films and inventory cards collected and assembled in the field were classified, combined, collated, interpreted, displayed and turned into organized scientific data. Although the information collected by the EFEO was in fact processed at the MET, this doesn't mean necessarily that the only site of knowledge production was the metropolitan museum. As Kapil Raj has recently argued, the 'circulatory perspective' may provide 'rich theoretical alternatives to the center-periphery trope' (2013: 347). Located in a colonial setting that was at the same time a site of collecting, the EFEO, by gathering and centralizing objects, texts, films, and photographs and dispatching them to the MET, as well as to other museums in French Indochina in places such as Hanoi, Hue, Laos, and Saigon, was also involved in the process of knowledge production. As will be argued in the next section, the EFEO issued specific methodological instructions for collecting objects that, although mirroring the metropolitan ones, were deemed to take into account the specificities of the site of collecting. Thus, as Raj puts it, 'the circulatory perspective allows one to see science as being co-produced through the encounter and interaction between heterogeneous specialist communities of diverse origins' (2013: 345).

The EFEO's collaborators were supposed to collect two exemplars of the same object, one for the MET, the other for the museum that was to be established at Dalat. This required two types of circulation: a local circulation (from the field to the local museum or to the EFEO's headquarters) and a global circulation from Indochina to Paris. By keeping duplicates of the inventory cards and sending their shelf number to the MET, the EFEO constituted an archive both for the metropole and for the colony. While the EFEO located at Hanoi was in charge of coordinating the collecting activities in the North of Indochina, the Oceanography Institute at Nha-Trang (South Vietnam) under the direction of Pierre Chevey, was supposed to play a similar role in deciding how collecting activities would be carried out in the South: that is, gathering artefacts, making inventories and sending them to the MET. ${ }^{19}$ 
If artefacts circulated from Indochina to Paris, visual and textual information associated with them was constantly requested by the MET from the local collectors: in other words, there was a back and forth movement of inventory cards, drawings, and photographs. Thus, it would be misleading to consider local collectors as mere providers of objects to the metropolitan museum; rather, local collectors participated, with their knowledge and expertise, in the development of Indochinese ethnology both in the metropole and in the colony.

Claeys and Colani's correspondence with Rivet and Bouteiller respectively provides useful information about the ways in which ethnologists and local collectors were involved in a chain of activities that went from collecting in the field, describing objects, sharing information, to mounting exhibits. In her detailed report on the arrival of a collection sent in July 1933, Bouteiller started by accurately depicting the physical conditions of the films, the photographs and of the 205 objects (broken, damaged, in need for conservation or repair) ${ }^{20}$ The issue of 'stability', in Latour's terms, was a constant preoccupation for local collectors, who had to ship objects on long voyages and also for metropolitan curators who had to repair them, classify them, and put on displays. That is the reason why the EFEO conceived specific boxes for the shipments, since objects had to travel on long routes around the world. In her report, Bouteiller mentioned the ways in which the objects received could complement and/or fill the gap at the MET's collections and how they were put in the showcases. Finally, she requested additional textual and visual information. For example in order to illustrate theatre costumes in the showcases, she asked for actors' photographs. ${ }^{21}$ Colani's advice was crucial for mounting the Asian gallery at the MET; in 1934 in a detailed letter to Colani, Marcelle Bouteiller described how Colani's collection was processed at the MET by means of the accessioning arrangements, how objects and photos were classified, what sort of information was attached to them and inscribed on the labels. ${ }^{22}$ In other words, Bouteiller specified the mechanisms of translation, by means of which the information collected in the field was organized at the MET; in addition, she was aware of the imbrication between the field, the collecting practices and the museum.

There was undoubtedly a hierarchy between collectors in the field and classifiers/ curators at the MET, who organized and interpreted the objects, inventory cards, photographs, and films, and by doing so created new systems of relationships between them. But it would be misleading to suggest that the MET devalued the knowledge produced by the EFEO's collaborators. Just after his return to France, Rivet sent to Claeys the inventory cards of the objects kept at the MET, and asked for information about the objects' provenance, use, and fabrication. ${ }^{23}$ In his responses dated from May and July 1932, Claeys provided the information required, and referred to the shipment of a duplicate list of objects, one list being attached to the letter, the other list sent along with the objects. He also detailed the methodology deployed for the objects' inventory: a letter referring to the first name of the collector and a number related to the collecting date. Claeys suggested to Rivet that additional information and details about the objects' provenance should be included in the inventory cards. According to Claeys, the MET's current object identification system, which was under general geographical categories, such as Tonkin and Annam, lacked precision, because there were at least twenty different ethnic groups in each geographical province. ${ }^{24}$ As an expert on the field, Claeys could argue that 'from Paris, Indochina looks like a homogeneous whole, while Indochina was, in fact, a carrefour, that is, a cultural crossroad' ${ }^{25}$ Claeys's suggestion was taken into account; in an inventory of the objects sent to the MET in October 1933, along with the designation 'Annamite group', the name of the village as well as of the province were mentioned, ${ }^{26}$ an example that attests to the ways in which the field collector imprints his colonial knowledge on the objects collected. It is worth noting that this inventory was complemented by information (drawings, photographs, and textual information) provided by Claeys.

In addition to being the coordinating centre of a network of collectors operating in different sites of collection, the MET also functioned, along with the IEP, as the headquarters from which missions would receive instructions on what and how to collect. The issue of standardization implying established conventions for naming and classifying objects on the one hand, and filing inventory cards on the other, was crucial for the circulation of objects and information. 


\section{Inventory Cards, Collective Practices, and Standardization}

During his mission in Indochina and even after his departure to France, Rivet was constantly providing local administration with several copies of the Instructions sommaires pour les collecteurs d'objets ethnographiques, elaborated by the MET for the 1931 Dakar-Djibouti mission. ${ }^{27}$ In turn, the EFEO systematically reminded collectors to ask for these Instructions. The MET's inventory cards and labels as well as the Instructions were sent to the EFEO or to Claeys who, in turn, dispatched them to the EFEO's collaborators, local collectors ${ }^{28}$ and to the residents. ${ }^{29}$

Standardization by means of methodological instructions, inventory cards, files, notebooks, and labels was central to ethnology, as a collecting discipline grounded in collective practices. Robert Kohler (2007) has recently coined the term 'collecting sciences' - including anthropology along with systematic biology, geology and mineralogy - to distinguish sciences that focus on material objects from those that deal with verbal reports and/or numbers. One of the distinctive features of the collecting sciences is, according to Kohler, 'a particular kind of materiality', 'it is this "thing-y" particularity' (2007: 432). The other distinctive feature of the collecting sciences, deriving from their materiality, relates to the fact that collecting is 'an unusually complex social and cultural practice' requiring specific procedures for 'selecting, extracting, recording, and transporting objects from field to storage vault' as well as 'strategies for designing and assembling collections', 'methods of ordering and classifying objects' and 'the arts of preserving and curating that make collections of fragile objects permanent' (Kohler 2007: 432). French ethnology in the 1930s can be considered a 'collecting science' requiring a collective practice. Indeed, as Strasser notes, 'Because collecting was essentially a collective practice, carried out by different actors, the issue of epistemic and social coordination was essential' (2012: 315).

In 1933, the EFEO issued, in collaboration with the IEP, a specific methodological guide entitled Note pour les collecteurs de l'enquête ethnographique ${ }^{30}$, a title focusing on enquête, a term that, as Daniel Sherman has pointed out, is 'most easily translated as fieldwork but encompassing notions of collaboration as well' (2004: 683). In fact, one the most prominent characteristics of the EFEO's ethnographic research and of the MET's missions is the sense of a collaborative enterprise. In this sense, ethnology tends to pertain to what Lorraine Daston (2012: 162) defines as 'the sciences of the archive'. Daston writes:

What distinguishes the sciences of the archive from other sciences is not just the phenomena they study nor even the practice of taking, making, and keeping data. Rather, it is practices of collection, collation, and preservation conceived as an intrinsically collective undertaking - and one that extends into both past and future (2012: 162).

This 'collective undertaking' or 'a sense of a community of inquirers' as Daston puts it, is a characteristic feature of the sciences based on collecting practices.

The EFEO's Note followed the main principles formulated by the 1931 Instructions $^{31}$, particularly the emphasis on the notion of an object as a document itself and on ethnography as 'the science that deals with the archives of man'. Consequently, ethnography's aim was 'to assemble the documents for the study of material civilization', a documentary concern that presupposed assembling artefacts, photographs, films, and maps (Jamin 1982; 1985). Along with the 1931 Instructions, Mauss's courses at the IEP (where from 1925 he taught a course entitled 'Instructions in Descriptive Ethnography') were aimed at 'constituting scientifically the archives of archaic societies' (Mauss 1967:7).

Thus, according to Mauss 'the museography of a society consists of establishing material archives of it, museums are the archives' (1967:16). The archival dimension ascribed to the ethnographic museum was made possible thanks to the operations of inscription and translation of information in written and visual forms. To a certain extent, the archival dimension in ethnology goes beyond the collecting of objects and extends to the collecting of field notes, photographs, kinship terms, sound recordings, drawings, and films. It can therefore be seen that the specificity of French ethnology in the 1930s resides in this combination of the museum and the field, envisioned as complementary settings providing materials, seen as documentary 
materials, deemed to be useful for future generations. As Lorraine Daston clarifies, 'It is not just a deep time dimension in the phenomena investigated that is the hallmark of the sciences of the archives, but rather the practice of storing up materials for future investigators'(2012:161). The 1931 Dakar-Djibouti mission illustrates this documentary or archival dimension ascribed to ethnology (Jamin 1982), and its outcomes were described by Rivet and Rivière as a list: 3,500 ethnographic objects, notations of 30 languages or dialects, collections of ancient and modern Ethiopian paintings, 300 Ethiopian manuscripts, 6,000 photographs, 200 sound recordings and 15,000 fiches descriptives (Rivet and Rivière 1933). Far from being specific to ethnology, the constitution of archives 'of the most diverse forms' in the natural and the human sciences 'make cumulative, collective knowledge possible' (Daston forthcoming). ${ }^{32}$ French ethnology can be considered as pertaining to the 'sciences of the archives', and as an archival science itself, sharing common practices with other disciplinary fields. ${ }^{33}$

Far from being a mere copy of the metropolitan Instructions, the EFEO Note was an adaptation to Indochina of the protocols guiding the practices of collecting which took into account the very fact that most of the investigators were not trained in ethnology. Yet, the ways in which the information collected in the field was inscribed in the fiche descriptive (inventory card) followed the standardized model elaborated by the MET. The first procedure consisted of 'translating' an object into a number. Each object was given a number; the object's number was inscribed in diverse surfaces - on the object itself, in the fiche descriptive, in the inventory, and in the carnet de route (field notebook) - as a means of 'avoiding errors' ${ }^{34}$

The second procedure consisted of transcribing the information collected in the field in a fiche descriptive. The EFEO Note explicitly referred to the MET's fiche descriptive (a Bristol card with a standardized size $13.5 \times 19.5 \mathrm{~cm}$ or 5 by 8 inch sheet of paper) as the main tool for describing objects. The very idea of a duplicate (thanks to the carbon copy) meant that one of the fiche descriptive was to be sent to the EFEO's director, who, in turn, would send it to the MET, while the other was to be kept in the collector's archive, according to the 1931 Instructions.

Why was it important to have duplicates of the fiche descriptive? One of the main reasons was related to the possible loss of the fiche descriptive during journeys from peripheral locations to the metropole. The other reason has to do with the division of intellectual labour. The fiche descriptive kept at the MET was physically located in a file that was accessible to other ethnographers. Moreover, the fiche descriptive should be constantly updated with new information provided by the collectors in the field. Claeys sent to Rivet a detailed descriptive list with the objects' numbers and its shelf number in the fiche descriptive kept at the EFEO; since there were to be copies of the fiche descriptive, one at the site of collection, the other at the metropolitan museum, that allowed for the circulation of information in both directions. Consequently, the very 'model' of the fiche descriptive was constantly updated and transformed each time it circulated. The third procedure consisted of registering the objects. The very first task of the enquêteurs consisted of having a field notebook where the names of his or her 'agents of information' could be noted, and the methodological precepts and the details about the objects be consigned.

The information to be inscribed in the fiche descriptive referred to the object's number, the ethnic group, the provenance (country, village, and province), the object's name in French and in the indigenous language, the object's description (material, form, colour, decoration, dimensions, and weight), information related with the object's fabrication, use, ideas and beliefs associated with it, the donor's name, the date of the mission, the numbers of the photographs, drawings, and/or films and the pages of the carnet de route related to the object. ${ }^{35}$ Far from being a mere textual device, the fiche descriptive was to be complemented with photographs, drawings, and films that would help to visualize the ways of using and handling the objects. It was this combination of textual and visual information that conferred on the artefact the status of an ethnographic object worthy of being displayed.

It was thanks to these three procedures that objects, texts, films, drawings, and photographs collected in the field were organized in the museum and translated into inscription devices. Standardization by means of fiches descriptives, shelf numbers, labels, and inventories made it possible for information and objects to circulate from colony to metropole and vice versa. Although collectors were expected to follow the methodological procedures, consigning 
information to the fiche descriptive required quite a considerable amount of time. As a result, some collectors ended up by just sending lists of objects to the MET. Colani's list of objects ${ }^{36}$ contained six neat columns labelled for each kind of information: the object's number; its geographical provenance; the object's description; material; function and ethnic group.

By including certain types of information judged relevant and excluding others, the fiche descriptive served as both a tool for the accumulation of knowledge; and a means of organizing knowledge in a standardized way, making it available to other researchers and allowing for the updating of information. Information thus circulated 'from hand to hand, as objects circulated toward museums', as part of what Ricardo Roque calls a 'miniature historiography' that 'circulates in labels, catalogs, registers, and correspondence of museums and their agents' (2011: 13).

The objects, files, fiches descriptives and photographs kept at the MET were intended to promote scientific and popular knowledge about Indochina for metropolitan populations. As a result, this institution was fulfilling its 'national role' according to Rivet, as 'an instrument of cultural and colonial propaganda' (Rivet 1936: 7.08.5). The Indochinese collections were displayed for the metropolitan public in accordance with the principles of a new humanistic universalism made up of different, but ostensibly equal, racial types and cultures. It was during this time that new governmental conceptions of the relationships between France and its colonies took shape under the notion of Greater France, which regarded colonies as integrative parts of the French nation that were to be valued for their contribution to the cultural diversity of the colonial power. In Indochina, collecting practices were much less likely to result in exhibitions; collections were primarily addressed to administrators, colonial personnel and tourists, as Rivet himself acknowledged in 1936; 'Ethnographic centers and local museums in the colonies would allow tourists, colonials and civil servants to document in situ the customs of the populations they visited, with whom they worked or who were under their administration' (Rivet 1936: 7.08.5). At the same time colonial policies were promoting Indochinese cultures as essentialized entities encouraging indigenous people to return to their traditions. As a result, collecting practices entailed distinct government effects in France and in colonial Indochina.

\section{Concluding remarks}

In a letter to Rivière dated February 1932, Rivet claimed that Claeys 'would thus do for Indochina what Griaule is doing for French West Africa' (quoted in Conklin 2013: 216). But this wishful thinking was not achieved for several reasons. First, although the EFEO progressively extended its capacities to include ethnology and the study of contemporary ethnic groups by creating in 1937 an Ethnological Service responsible for conducting surveys and for organizing several ethnographic museums under the direction of Paul Lévy, the Orientalist tradition still shaped the theoretical framework of the EFEO's research agenda and favoured the study of the two great 'civilizations' - the Indian and the Chinese. As for Lévy himself, he co-founded in 1938 the Institut Indochinois pour l'Étude de l'Homme, an institution primarily devoted to anatomy and physical anthropology. Second, from 1933 onwards, Claeys constantly complained to Rivet about the lack of funding to the extent that he questioned his own capacity to carry on the tasks he had been assigned. In 1934, at a time when the MET was in a difficult economic situation due to the Depression, Rivière asked Claeys to reduce the costs of transportation, arguing that he had already spent 7,000 of the 20,000 francs allocated for envoys to all the MET's departments. ${ }^{37}$ The financial situation might help to explain why Claeys gradually left aside collecting objects and turned instead to films and photographs.

Third, Rivet's quotation illuminates his aim of setting up an institutional network of museums and research institutions operating in different French colonies under his own directorship (Dias 2014). Written during his mission in Indochina, Rivet's letter reflected his enthusiasm for the development of a new field of inquiry and tended to overestimate Claeys's achievements. As Mus later remarked at the 1937 Congrès de la recherche scientifique dans les territoires d'outre-mer, the EFEO 'might take an interest in ethnology but would not specialize in it and would never become an outpost of the Musée de l'Homme. At best, it would serve as a relay between field-workers and Paris' (quoted in Conklin 2013: 225). 
Establishing a network of museums and research centres across French colonies was not a mere tool for organizing knowledge; it was indeed a means of entangling ethnology with colonial practices. As Tony Bennett noted, the MET by means of 'its management of the cultural flows from colony to metropolis, and its role in the administrative flows going in the opposite direction' was placed 'at the intersections of the processes through which the work of "making culture" and "changing society" was articulated across metropolitan and colonial contexts' (2013: 91). The role played by the MET in processes of colonial governing has been analyzed by Benoît de l'Estoile and Alice Conklin from quite different perspectives. While for de l'Estoile, the MET was a part of a developing institutional complex of colonial governance in Indochina as well as in French West Africa (2007: 122-30), Conklin sees this museum as having a more detached relationship to the processes of colonising. As she pointed out 'Yet for all Mauss's and Rivet's embrace of the empire in the 1930s - from the launching of the Mission Dakar-Djibouti and association with the Colonial Exposition to the cultivation of overseas outposts - they and their team remained detached from the actual work of colonizing' (Conklin 2013: 231). Thus, she aptly characterizes French ethnology as 'a science inside and outside the Empire' (2013: 230).

The colonial situation called on ethnology to conceive its object of study - colonised societies - as an object of intervention. But at the same time, it was the colonial context that required ethnology to be both a scientific practice and a social practice, deemed to 'correct' the errors of colonial administration and to foster 'humane colonial policies'.

The circulation of objects and information thus highlights the ways in which local collectors, native informants, administrators, and scholars involved in collecting practices were simultaneously active agents in the making of ethnological knowledge. The colonial context of collecting shaped collectors' views on objects and the role ascribed to native informants; conversely, collectors' colonial experiences and knowledge inflected the ways in which objects and information were selected and collected. Moreover, fiches descriptives, labels, lists, and inventories went back and forth between Paris and Indochina, and in the process of circulation, ended up transforming themselves. A close analysis of this 'epistemic circulation' that 'drew trajectories that were not necessarily coincidental to the physical movements of objects' (Roque 2011:15) might shed light on the workings of ethnology in the colonial context.

Received: 2 September 2013

Finally accepted: 15 January 2015

\section{Notes}

1 This French term for 'ethnology' was coined in the early twentieth-century in opposition to 'anthropology', which was equated with physicalanthropology.

2 Letter from É. Senart to L. Finot, Bulletin de l'École Française d'Extrême-Orient (thereafter BEFEO) 1901: 9.

3 L. Finot, 'Les Études Indochinoises', BEFEO, 1908: 233.

4 Instruction pour les collaborateurs de l'École Française d'Extrême-Orient, Saigon: Imprimerie commerciale Ménard \& Legros, 1900.

5 M. Mauss, 'Extrait de la "Leçon d'ouverture à l'enseignement de l'histoire des religions des peuples non civilisés"' in M. Mauss 1969: 369.

6 L. Aurousseau, 'Claude-Eugene Maître', BEFEO 1925: 599-624.

7 Letter from Mauss to Coedès, 24 June 1930 quoted in Fournier 1994: 588. Georges Coèdes was EFEO's director from 1929 to 1947.

8 French-ruled Indochina encompassed a federation of colonies and protectorates: this included the colony of Cochinchina (the southernmost part of modern Vietnam) and the protectorates of Laos, Tonkin (in north Vietnam), Annam (the central region of present-day Vietnam) and Cambodia. 
Located in the hills of Southern Vietnam, Dalat was built as a city for white colonizers and was equipped with the cultural and social amenities comparable to those of European metropolitan centres; hence it was decided an ethnographic museum should be created there, a project continuously postponed and finally abandoned in 1935. On Dalat, see Jennings 2011.

10 On the relative absence of Asian collections at the MET before 1930, see letter from Rivet to Claeys, 19 April 1932. Carton XV, dossier 19. Archives de l'École Française d'ExtrêmeOrient (EFEO), Paris. The Asian ethnographic collections from the MET were transferred, due to the lack of space, to the Musée Guimet in Paris in the 1890s (Dias 1991: 186).

Letter from Rivet to Claeys, 11 March 1932. Carton XV, dossier 19. Archives EFEO. Jeanne Cuisinier collected 468 objects in 1932-1934 and in 1945 (Pelras 2001).

Letter from Rivet to Claeys, 20 February 1932. Carton XV, dossier 19. Archives EFEO.

'Liste additive des objets réunis par Mlle Karpelès destinés au Musée du Trocadéro', January 1934. Carton XV, dossier 19. Archives EFEO.

BEFEO, 33, 1933: 419.

Dossier Madeleine Colani. Carton XV DP P 107. Archives EFEO.

Letter from Bouteiller to Colani, 18 September 1932. Dossier Colani, carton XV DP P107. Archives EFEO.

Letter from Claeys to Rivet, 24 July 1933. Carton XV, dossier 19. Archives EFEO.

Letter from Claeys to Rivet, 9 July 1934. Carton XV, dossier 19. Archives EFEO. On Devereux's collection of 713 objects collected between 1933 and 1934, see Dupaigne 2001: 142.

Claeys, 'Notice sur l'enquête ethnographique', BEFEO, 1933: 479.

Marcelle Bouteiller, 'État d'arrivée de la collection expédiée en juillet 1933', Carton XV, dossier 19. Archives EFEO.

Marcelle Bouteiller, 'État d'arrivé...', Archives EFEO [We don't use location references like idem, so I've reformatted this as I think appropriate]

See: Dossier Colani, XV DP P 107. Archives EFEO.

Letter from Rivet to Claeys, 19 April 1932. Carton XV, dossier 19. Archives EFEO.

Letter from Claeys to Rivet, 6 July 1932. Carton XV, dossier 19. Archives EFEO.

Claeys, 6 July 1932. Archives EFEO

'Inventaire descriptif des objets expédiés au Musée du Trocadéro en Octobre 1933'. Carton XV, dossier 19. Archives EFEO.

Letter from Rivet to Monsieur le Résident aux administrateurs, 2 May 1932. 2 AM G 2e. Archives du Musée du quai Branly, Paris.

Letter from Claeys to Rivet, 9 May 1932. Carton XV, dossier 19. Archives EFEO.

Letter from Claeys to the Résidents, 24 May 1932. Carton XV, dossier 19. Archives EFEO. 
30 'Note pour les collecteurs de l'enquête ethnographique organisée par l'École Française d'Extrême-Orient', BEFEO, 1933: 479-85.

31 Instructions sommaires pour les collecteurs des objets ethnographiques, Paris: Musée d'Ethnographie du Trocadéro, 1931.

32 Lorraine Daston, 'Third Nature' in Lorraine Daston ed., Science in the Archives: Pasts, Presents, Futures (forthcoming).

33 For a detailed discussion of the terms 'sciences of the archive', 'science in the archives' and 'scientific archives', see Daston 2012 and forthcoming.

34 Instructions sommaires pour les collecteurs des objets ethnographiques, 1931: 23.

35 'Note pour les collecteurs de l'enquête ethnographique organisée par l'École Française d'Extrême-Orient', BEFEO, 1933: 481-3.

36 'Liste des objets remis par Mademoiselle Colani pour être expédiés au Musée du Trocadéro, Octobre 1933'. Carton XV, dossier 19. Archives EFEO.

37 Letter from Rivière to Claeys, 12 April 1934. Carton XV, dossier 19. Archives EFEO.

\section{References}

Bennett. T. (2013) Making Culture, Changing Society, London and New York: Routledge.

Bert, J.B. (2011) “'De l'utilité des recherches de sociologie descriptive dans l'Indochine française", un manuscript inédit de Marcel Mauss (1902)', Genèses, 84, 143-59.

Clémentin-Ojha, C. and Manguin P.Y. (2001) Un siècle pour l'Asie: L'École française d'Extrême-Orient, 1898-2000, Paris: Les Éditions du Pacifique.

Conklin, A. (2002) 'The new "ethnology" and "la situation coloniale" in interwar France', French Politics, Culture \& Society, 20(2) 29-46.

Conklin, A. (2013) In the Museum of Man: Race, Anthropology, and Empire in France, 18501950, Ithaca and London: Cornell University Press.

Daston, L. (2012) 'The Sciences of the Archive', Osiris, 27(1) 156-87.

Dias, N. (1991) Le Musée d'Ethnographie du Trocadéro (1878-1908). Anthropologie et Muséologie en France, Paris : Presses du CNRS.

Dias, N. (2014) 'Rivet's Mission in Colonial Indochina (1931-1932) or the failure to create an ethnographic museum', History and Anthropology, 25(2) 189-207.

Dupaigne, B. (2001) 'Histoire des collections d'Asie du Musée de l'Homme', Outre-Mers, 88, $129-52$.

Fournier, M. (1994) Marcel Mauss. Paris: Fayard.

Jamin, J. (1982) 'Objets trouvés des paradis perdus: À propos de la Mission DakarDjibouti', in J. Hainard, and R. Khaer (eds) Collections: Passion, Neuchâtel: Musée d'ethnographie. 
Jennings, E. (2011) Imperial Heights: Dalat and the Making and Undoing of French Indochina, Berkeley: University of California Press.

Kohler, R. (2007) 'Finders, Keepers: Collecting Sciences and Collecting Practice', History of Science, xlv, 428-54.

Latour, B. (1987) Science in Action: How to Follow Scientists and Engineers through Society, Cambrigde, MA: Harvard University Press.

L'Estoile, B. de. (2007) Le Goût des Autres. De l'Exposition coloniale aux arts premiers, Paris: Flammarion.

Mauss, M. (1903) 'Essai d'une instruction pour l'étude sociologique des sociétés indochinoises', Premier Congrès International des Études d'Extrême-Orient, Compte rendu analytique des séances, Hanoi: F.H. Schneider.

(1967) Manuel d'Ethnographie (originally published 1947), Paris: Éditions Payot.

(1969) 'L'ethnographie en France et à l'étranger' (1913), in V. Karady (ed) Cohésion sociale et divisions de la sociologie, Oeuvres, 3, 395-434, Paris: Les Éditions de Minuit.

Pelras, C. (2001) 'Les Collections d'Insulinde du Musée de l'Homme', Archipel, 62, $163-$ 208.

Raj, K. (2013) 'Beyond Postcolonialism... and Postpositivism. Circulation and the Global History of Science', Isis, 104, 337-47.

Rivet, P. and Rivière G.H. (1933) 'La Mission ethnographique et linguistique Dakar-Djibouti', Minotaure, 2, 3-5.

Rivet, P. (1936) 'Ce qu'est l'ethnologie', in L. Febvre, and A. de Monzie (eds)

L'Encyclopédie française, 7, 7.06.1-7.06.8; 7.08.1-7.08.16, Paris: Librairie Larousse.

Roque, R. (2011) 'Stories, Skulls, and Colonial Collections', Configurations, 19, 1-23.

Sherman, D. (2004) '“Peoples Ethnographic”: Objects, Museums, and the Colonial Inheritance of French Ethnology', French Historical Studies, 27(3) 669-703.

Sibeud, E. (2004) 'Marcel Mauss: "Projet de présentation d'un bureau d'ethnologie" (1913)', Revue d'Histoire des Sciences Humaines, 1(10), 105-15.

Singaravélou, P. (2009) L'École française d'Extrême-Orient ou l'institution des marges (1898-1956), Paris: L'Harmattan.

Strasser, B. J. (2012) 'Collecting Nature: Practices, Styles, and Narratives', Osiris, 27(1) 303-40.

\section{Acknowledgements}

This research is part of the 'Museum, Field, Metropolis, Colony: Practices of Social Governance', an Australian Research Council Discovery Project (Award Number DP 110103776). Previous versions of this paper were presented in 2012 at Cultural Crossroads conference in Paris and in 2013 at Green College, University of British Columbia, Vancouver. I would like to thank Tony Bennett, Fiona Cameron, Conal McCarthy, Nuno Porto, Anthony Shelton, Catherine Soussloff and Mark Vessey for their helpful comments and suggestions. 
*Nélia Dias is Associate Professor at the Department of Anthropology (ISCTE-IUL Lisbon). She is the author of two books, Le Musée d'Ethnographie du Trocadéro: Anthropologie et Muséologie en France (CNRS1991) and La Mesure des Sens: Les Anthropologues et le Corps Humain (Aubier 2004) and of several articles dedicated to the practices of collecting artifacts, the cultural underpinnings of physical anthropology collections and to the history of French anthropology. She is currently working on the changing relations between museum practices and the governance of metropolitan and colonial populations in former French Indochina.

Department of Anthropology

ISCTE-IUL

$\mathrm{Av}^{\mathrm{a}}$ das Forças Armadas,

1649-026

Lisbon,

Portugal

+351217903000

email: nelia.dias@me.com 